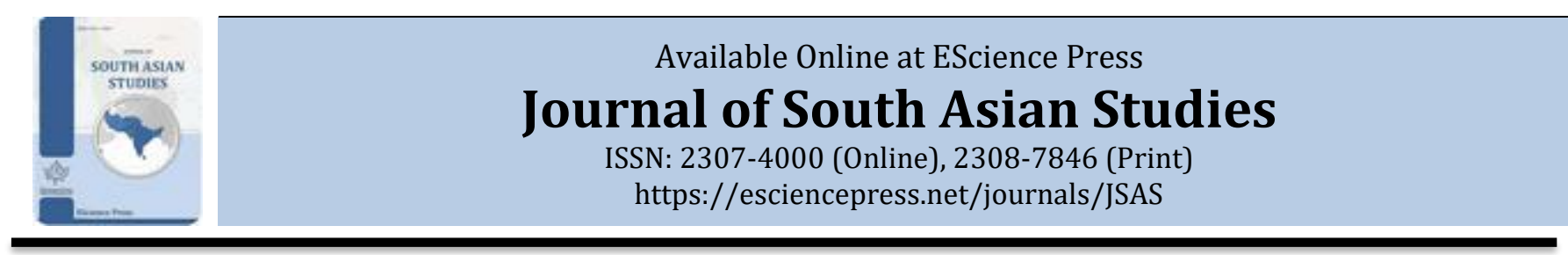

\title{
Pakistani Police Governance and Accountability: Challenges and Recommendations
}

aAthar Rashid*, bInamullah Jan, cMunib Ahmed

a Department of Governance \& Public Policy, National University of Modern Languages, Islamabad, Pakistan.

b Department of Politics and International Relations, International Islamic University, Islamabad, Pakistan.

c Department of Chinese Language and Literature, National University of Modern Languages, Islamabad, Pakistan.

*Corresponding Author Email ID: atharrashid@numl.edu.pk

\section{A B S T R A C T}

The persistence of massive corruption, a lack of accountability, departmental clashes, constitutional crisis, and a deteriorating law and order situation, particularly in the police department, are ample indicators of the country's poor governance. Pakistan has been engulfed by opinionated volatility and turbulence, resulting in the formation of a dark crevice in the country's economic growth and development. Good governance cannot be respected while there is opinionated disarray, a politician's appetite for power, and an unreformed Police Department. The current police system in Pakistan was designed by the British in 1861 to address a more diverse set of social, administrative, and political realities than the country currently portrays. Numerous national and international experts have concluded that colonial architecture is unsuitable for Pakistan. Pakistan requires comprehensive police reforms as a necessary component of the national framework, regardless of which party is in power. The public interest in reclaiming law enforcement's value has never been greater than it is today. There is growing recognition that the assignment requires concentrated effort. There can be no expectation of momentous police reforms without a continuing corporation and partnership edifice among the major players involved. A progressive and unwavering political leadership, a towering altitude of public support, and an enthused and well-led public that demands higher standards of police performance are all necessary components of change and good governance.

Keywords: Pakistan, Police, Corruption, Accountability, Local Electoral Authorities, Policing, Democracy.

\section{INTRODUCTION}

Undoubtedly, Pakistan's police force is regarded as the most corrupt in the country. They are primarily, if not exclusively, blamed for the breakdown of law and order as well as the steady deterioration of the country's scandalous justice system. Apart from its impact on law and order, police corruption is also to blame for the country's poor governance (Fair2009) It is argued that police corruption is simply a reflection of Pakistani society's corruption. Furthermore, police officers have the power to detain, arrest, and use force against anyone for personal or illegal gain. There is no system in place to hold them accountable for their illegal activities. If they are ever brought up on charges, their brothers in uniform deflect all attempts to convict them because they conduct all the investigations (Ali, 2010).
In this regard, the public is most concerned about police accountability. Excessive force, brutality, and corruption are all examples of police misconduct that frequently appear in the news and on social media. These incidents show that law enforcement agencies have systemic organizational issues (LEAs). According to Naveed (2009), scholars have noted that attempts at police reform have placed too much emphasis on individual bad behavior rather than the department's systemic problems. In this article, an attempt will be made to address the key internal police system that contributes to corruption, as well as a strategy for dealing with it. So far, the police department's upper management has taken minimal steps to prevent the alarming rise in corruption within its ranks, which has paralyzed society.

Until now, explanations for police corruption have relied 
on the proliferation of ruthless laws and rules, as well as the adoption of farmed social accountability to deal with police transgressions. All assessments and analyses of Pakistan's police force's organization and operation argue that the existing rules and suggested actions have not only been botched to produce any encouraging results but have also been harmful and detrimental. Instead of holding the police accountable for their role in dealing with crimes or mitigating corruption, solutions to police corruption should focus on social accountability mechanisms. As a result, this issue should be approached with caution while considering the derivation and should be backed up with the greatest possible political commitment; otherwise, a flourishing and reformist Pakistan will remain a pipe dream.

\section{DRAW ROUND OF POLICE}

The word "police" comes from the Greek word Polis, which means "city." The police intend to protect people from crime while also strictly enforcing the rule of law (Das \& Otwin, 2012). The rules and responsibilities during the period of empires were to establish law and order, as well as to protect private and public property and maintain the state's peace. Before the British came to power, rulers were the only ones who could administer justice, and no one ever questioned their authority or knowledge because they used to settle disputes amicably (Niaz, 2006). To get a better understanding of the police department, the scholar believes that the topics of discussion should be limited to the most important aspects of police in Punjab Province. Punjab is Pakistan's most populous province, with a plethora of policing issues due to the coexistence of people from various cultures. Their differences result in a law-and-order problem as well as dominance over most of the society (Siddiqa, 2009).

Punjab, which has its headquarters in Lahore, has the most police officers with 1,77,635 officers, including 9 Regional Police Officers, 4 City Police Officers, 1 Capital City Police Officer, and 35 District Police Officers. The investigation, Punjab Highway Patrol (PHP), Traffic, Elite Force, Special Branch, Counter-Terrorism Department, and Punjab Constabulary are all part of the provincial police force. Inspector-General of Police oversees all these agencies, and each department has its own Additional Inspector General of Police. The Punjab Police force consists of an IGP, 14 Assistant IGPs, 260 AIG/SSP/SPs, 808 ASP/DSPs, 3527 Insps, 21443 SI/ASIs,
6850 Tfc Wardens, and 144699 HC/Constables. The Inspector General of Police serves as an ex-officio secretary to the Punjab Government. (Police Punjab, 2020).

The Federal Public Service Commission and the Provincial Public Service Commission conduct tests to recruit police officers. The Punjab government has spent and set aside millions of dollars to train and specialize police officers in their fields. The establishment of a Cyber Crime Unit at the provincial level, as well as IT experts at the district level, has greatly aided in the process of completing investigations quickly and improving the quality of their work. The department of training is working hard to meet the police's top management's goals to meet the most recent and modern challenges. Terrorism has become deeply rooted in our country since the attacks on the twin towers in the United States. Special Branch and the Counter-Terrorism Department (CTD) are effectively combating the threat of terrorism to restore peace and government jurisdiction (Police Punjab, 2020).

\section{INTRICACIES CONFRONTED BY POLICE}

The police department is confronting the following intricacies at various levels. A few of them are narrated as under.

\section{Incompetent Professionals at Lower Ranks}

Our police force is modeled after the Irish Constabulary, whose primary duties were to control and oppress the populace, as police officers were never considered to provide public services. Around 90 percent of the police force is made up of officers with the rank of constable or head constable (Khan et al., 2010). While serving in the same ranks, police officers become exhausted and seek legal help from the court and judiciary, who do not assist them in making timely decisions, resulting in utter frustration, bribery, and abuse of authority. In Punjab province, there are 144,699 police officers (constables and chief constables) assigned to various locations (Annual Administration Report, 2011). The annual rate of retirement, death, and actions on serious offenses against middle and higher ranks is said to be 9 percent.

\section{Financial Constraints}

One of the most significant impediments to the police's ability to function properly is a lack of sufficient financial assets. Officials from the police station, district, and 
provincial levels confirmed that they did not have the necessary funds to carry out their duties properly (Siddiqa, 2009; Khan et al., 2010; Niaz, 2006; Naveed, 2009; Ali, 2010; Fair, 2009).

\section{Inadequate Transport Facilities}

Officials from the police force complain about a lack of funding for fuel and vehicle maintenance. They are required to operate in large areas, but they are short on fuel and operate in old vintage vehicles that need maintenance, preventing them from performing their essential functions such as investigation, routine beat walks, and timely response to calls for assistance (Siddiqa, 2009; Khan et al., 2010; Niaz, 2006; Naveed, 2009; Ali, 2010; Fair, 2009).

\section{Excessive Control of the Civil Bureaucracy}

The main problem preventing the police system from carrying out its duties properly is the civil bureaucracy's unprovoked interference. The civil bureaucracy refused to change Police Order 2002 because it obliterated the district magistrate's authority over the police. As a result, the bureaucracy attempted to delay the law's implementation by exerting pressure on the powerful to change the essentials of the new legislation (Siddiqa, 2009; Khan et al., 2010; Niaz, 2006; Naveed, 2009; Ali, 2010; Fair, 2009).

\section{Mistreatment of the Lower Ranks}

Lower-rank officers are frequently treated harshly, which demoralizes them. The report on disciplinary action in the Punjab police department clearly demonstrates higher-ranking officials' rudeness and abusive language toward lower-ranking officials. In 2011, 54800 police officers were disciplined because of various cases, with 34061 of them being low-ranking officers. (2011 Annual Administration Report) It means that all wrath is directed at lower officers because they lack a channel through which to express their dissatisfaction with their superiors' behavior (Siddiqa, 2009; Khan et al., 2010; Niaz, 2006; Naveed, 2009; Ali, 2010; Fair, 2009).

\section{Biased Hiring of Police Personnel}

Unfortunately, officers are promoted solely based on political favoritism. Junior officers are coerced to obey any orders given in this way, and when an inquiry is set up to investigate such illegal orders; low-rank officers are punished and demoted. As a result, lower-rank loyalty shifts away from the state and toward political patronage. Even these officers seek postings and promotions based on political loyalty because of their services to the selfinterests of political coercion (Siddiqa, 2009; Khan et al., 2010; Niaz, 2006; Naveed, 2009; Ali, 2010; Fair, 2009).

No Defined Duty Hours: The police's working hours are not set in stone, as they are required to work almost 24 hours a day, in contrast to the Motorway Police who are only on duty for 8 hours, despite having higher performance and commitment levels than Punjab Police. These long working hours leave them with no means of boarding, lodging, or transportation. Because of their low salaries, police officers can't even afford to live in a rented house that meets their needs. Police officers in large cities are forced to live in slums near criminals. Living in these areas develops a nexus with criminals for their own agendas (Siddiqa ,2009; Khan et al., 2010; Niaz, 2006; Naveed, 2009; Ali, 2010; Fair, 2009).

\section{Feudalism Hinders Police Performance}

Pakistan is a country where feudal lords have complete control over all departments and are rarely held accountable for misdeeds committed during their reigns. Furthermore, they do not bring about reforms that will provide justice and a higher standard of living for the remaining 220 million people. Their power in the police force cannot be tolerated. The majority of the country, including Punjab, Sindh, and Balochistan, is ruled by feudal lords, and the police are largely loyal to their feudal mindsets (Siddiqa, 2009; Khan et al., 2010; Niaz, 2006; Naveed, 2009; Ali, 2010; Fair, 2009).

\section{CONCEPTUALIZATION OF ACCOUNTABILITY}

- Accountability refers to account holders' obligation to accept responsibility for their actions. People with political, financial, or other forms of power, such as government officials, civil society organizations, international financial organizations, and private corporations, are account holders. Day and Klein (1987) define accountability as a means of establishing relationships between actors by determining who is responsible for performing a specific duty and who has the authority to hold others accountable after they have completed that duty (Gray and colleagues, 1997). Accountability is not only a tool for judging an individual's or a group's behaviour and performance, but it also 
provides a mechanism for assessing those behaviors (Mulgan, 2003).

- Accountability in this context can lead to change because of one's actions. Being accountable entails more than just providing information; it also entails the ability of those to whom one is accountable to effect change in their actions. Mulgan (2003) coined the term "rectification" to describe this process. Another study links it to the ability to levy a fee (Keohane, 2002). The weaker members of society lack power, and they do not hold the powerful to account for their actions. As a result, they will need the assistance of other powerful people to hold government agencies accountable for their actions (Jenkins \& Goetz, 1999). Kilby (2004) describes the nature of downward accountability, in which public officials are held accountable to their electoral districts and local constituencies.

- Although accountability is implemented at various levels that are interconnected, it is not possible to achieve these at all levels at the same time. Public accountability has many facets, and public servants must be held accountable for their actions in front of their local constituents in a variety of ways (Boven, 2006).

\section{Types of Accountabilities}

The types of accountabilities are listed below.

\section{Political Accountability - Powerful Political Agents} i.e., Voters, Media: In democratic society the role of political accountability is of utmost importance. In this regard, accountability is consisting of principal-agent relationship (Strom, 2000). The delegation of power is transferred in the form of hierarchal chain moving from downward to upward and vice versa. The voter renders their sovereignty to the elected representatives and those elected representatives must keep their knees down and delegate their powers in front of the cabinet of ministry. The structure of political accountability merely operated in reverse direction to that of delegation (Strom, Muller \& Bergman, 2006). At some time, the representatives stood up for election render account to the local constituents (voters) at election time. Hence, the relationship is not merely a principle-agent between political stakeholder, but also forum and actor. There are two edges of chain (voter and public agent), and their role cannot be interchanged with each other. In addition, media has become one of the resonant powers as informal forums for political accountability (Elchardus, 2002).

Legal Accountability - Judicial Courts: The rocketed increase in the socialization gives ample raise to the legal accountability of government institutes specifically in the western world (Behn, 2001). Harlow (2002) discusses another important reason for the increase in legal accountability. He says that the existence of trust and transparent system of courts either these are ordinary civil courts (i.e., British courts) or specialized administrative courts (i.e., France, Belgium, and the Netherlands) as compared to parliaments. The element of legal accountability is generally related with responsibility which has legal and formal obligation upon authorities. Hence, it is the most explicit type of accountability because it is based on detail documentation covering legal standards as discussed by civil, penal, or administrative bodies.

\section{Administrative Accountability - Auditing, Inspection} and Controlling Bodies: Civil society institutions have initiated to exercise the independent supervisory role towards the administrative and financial side which is often named as "audit explosion" (Power, 1994). These institutions are varying from European, national, or local Parliamentary commissioner and audit offices to autonomous supervisory bodies, inspector, national accountability offices and chartered accountants. These audit offices or ombudsmen mandates have been developed to not only provide safety to the probity or legality of public spending but to increase its effectiveness and efficiency (Pollitt \& Summa 1997). It is the obligations of these institutions to analyze the financial and administrative affairs according to prescribed edicts and norms.

Professional Accountability: Many professionals serving on managerial posts trained as doctors, engineers, veterinarians, teachers, or police officers are well equipped with the technical knowledge of their respective fields (Freidson, 2001) Professional bodies device certain standards and codes of conduct to ensure that all members are following the provided codes of ethics to avoid from unpleasant events thereby resulting into introducing and promoting the culture of accountability. The professional supervisory bodies are liable to keep proper check and balance that either codes 
of ethics are followed or not. This type of accountability is more related with the public mangers working in hospitals, research institutes, policing, fire brigades or schools.

Social Accountability - Stakeholders, Civil Society Organizations, Charities: In recent democratic organizations there is a dire need to have direct and explicit accountability relationship among public agents and civilian (citizens, clients, civil society) to make the government system more transparent and reliable. (McCandless, 2001). Many debates have been conducted on corporate social responsibility and corporate governance in the business field. These concepts are majorly focusing on the role of NGOs, interest groups and customers in devising policies to make an actor accountable. (Rekenkamer, 2004) With the emergence of social accountability mechanism, the public agents are more indebted to account for their performance in front of the civil society organizations and interest groups. The emergence of internet has open new avenues to this type of public accountability. Social media websites help people to make official bodies and public institutes accountable for their actions.

\section{SOCIAL ACCOUNTABILITY AND ITS MECHANISM}

Social accountability (SAcc) is the burgeoning field that doesn't have any universally accepted definition yet of the broad range of measures that cascade into its remit (Joshi \& Houtzager, 2012). It is an approach to ameliorate the public accountability that based on the citizen and nonstate actors' actions. It may be explained as a series of strategies and actions that civilians of a particular state beyond voting are used to hold the government organizations, civil society, media, and other societal actors accountable for their performance and conducts (Malena \& McNeil, 2010). Boven, et al. (2008) state that to be socially accountable is not merely related with policy formulation but accounting is a key element to make an actor accountable. SAcc has created a sensitization to develop more transparent and overt mechanism of accountability between actor (public institutes) and forum (citizen or civil society) (McCandless, 2002).

There are two mechanisms of SAcc; the first one is related to the external accountability termed as a vertical mechanism. Whereas second is related with internal accountability named as horizontal mechanism. The election is the key example to explain vertical accountability. It is a blunt instrument that citizen owned to evaluate the state official's contenders and use the voting right to nominate limited number of these officials. So, this instrument helps citizen to hold state-owned institutions accountable for their actions. Unfortunately, the system is not enriched enough to provide a citizen with the opportunity to express their preferences on subject of discussion and to make their meaningful contribution in the public decision-making process. In this regard, there are numerous ways to create public pressure to make actors accountable for their actions.

Provision of media coverage to some unexpected events either positive or negative, file legal claims, public protest for some ordeal events, and interface meetings between local constituency and public actors etc are some of the ways to make an actor accountable (Jenkins \& Goetz, 1999). All these ways are informal mechanism to reward and sanction to create public pressure on governmental bodies. Elsewhere, the interest groups including citizen, civil society organization use some formal means as well of sanction/enforcement to change, different evidence presented to corruption control agency, filing a petition, or appealing in legislation. McCandless (2002) highlights the prevailing urge in many western democratic societies to have more transparent and explicit accountability structure in strengthening the relations between government bodies on the one hand and local constituents and civil society institutions on the other hand.

The horizontal mechanism is also called internal mechanism of the state (Schedler, Diamond \& Plattner, 1999). This internal mechanism ensures the internal accountability of the state in different forms. The first form of horizontal mechanism is 'political mechanism' which focuses on the legislative inquiries, constitutional constraints, and separation of powers. The second is 'fiscal mechanism' ensures the transparency in formal procedures develop for auditing and financial accounting. The third one is 'administrative mechanism' includes hierarchical reporting structures, transparent rules and procedures, public service code of conduct, public omissions, and morality of public sector norms. The fourth and last form is 'legal mechanism' based on corruption control agencies, judicial and supervisory body (Goetz \& Gaventa, 2001). 
The existence of hierarchical relationship between actor and forum is missing when holding social accountability because no formal obligation procedures are followed. A moral act of agencies to have a sense of obligation for them without having any legal accountability is termed as horizontal accountability. Another form which is the intermediary way to cater accountability is called administrative accountability, which deals with a public organization where the principal, minister or administrators watch the employee's behavior. The parliamentary commissions (ombudsman), auditors, supervisory authorities, and accountants have least power to influence on actor decisions and are not directly associated with hierarchal public organizations. Schillemans \& Bovens (2004) name this type of mechanism is diagonal accountability that constitute an intermediate forum. See figure no. 1.

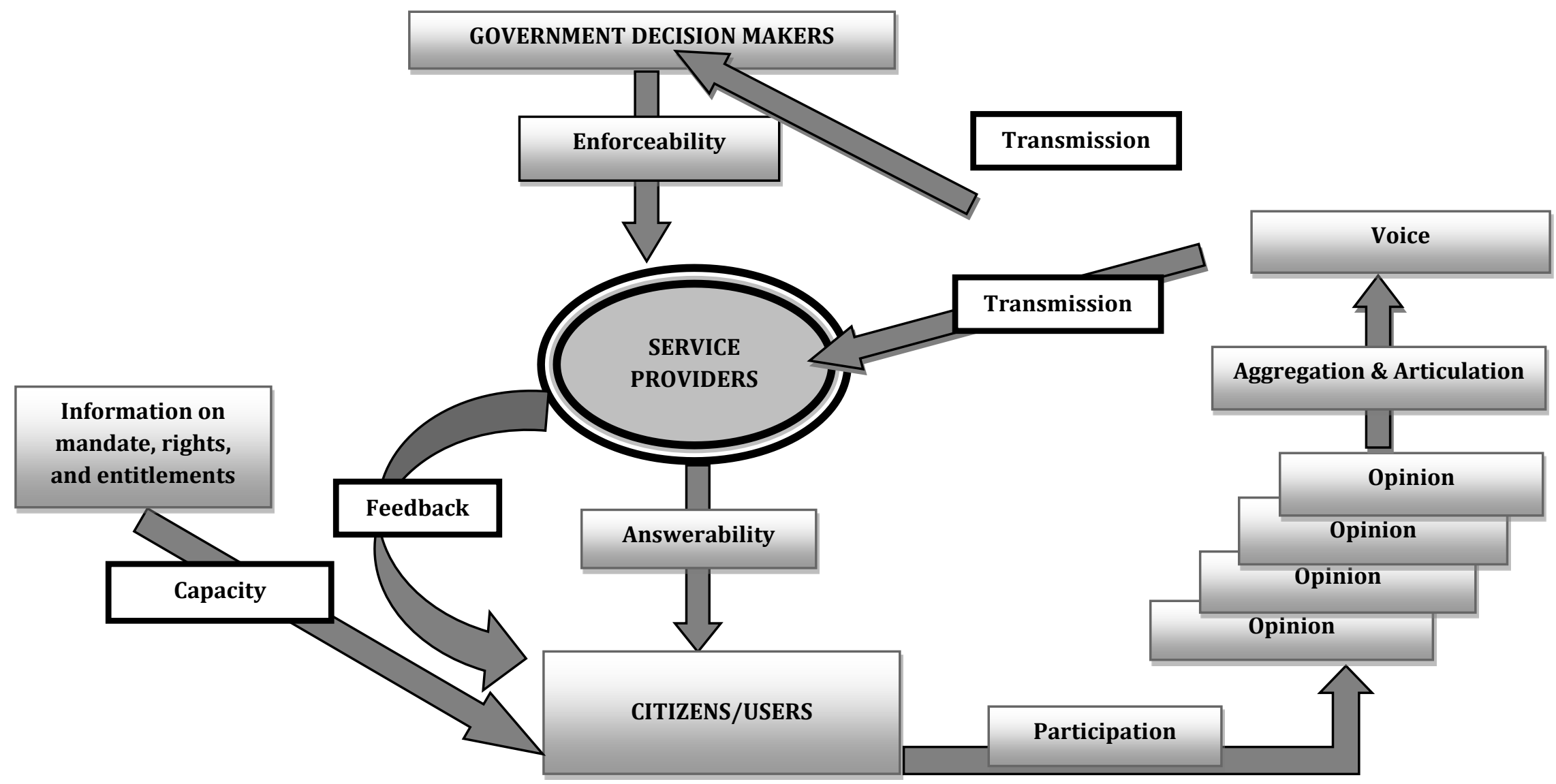

Figure 1: Components and Steps involved in Effective Social Accountability

Source: (Stahl, 2015: 7) 
In this regard, a very first step is the initiation of public panels and public reporting mechanism in various domains. The developments of internet specifically social networking sites give new perspective to this form of public accountability. These social networking sites have immensely used for assessments and inspections of various public personnel (Meijer, 2004). The relevant stakeholders including parents, principals, local councils, and journalists can easily compare the various reports either quantitative or qualitative of any department operating within same region. Similarly, the local institutions feel obliged to be publically accountable on the voices of parents after reading qualitative reports. There are three critical areas that collectively come under discussion when talking about SAcc mechanism (Sirker \& Cosic, 2007).

\section{Ameliorating Good Governance}

Due to the prevailing limitation in the formal accountability structure including the electoral system, SAcc tools and approaches have proved as the best potent strategies to promote good governance and reinforce the democratic systems. In addition, SAcc is playing a crucial role in providing a mechanism to monitor government performance, demand and enhance accountability. Similarly, SAcc reveals the government failures and misdeeds.

Enriching the Governmental Policies and Services Apparently, SAcc practices and approaches have often seen a simple mechanism that transparently link citizens with the state. In practice, it is a complex process in which many other actors of state institutions are involved and influenced the processes. Elsewhere, the prevailing social structure is also of the utmost importance in making SAcc mechanism more muddled. The report of World Bank (2003) has redefined the ranges of actions involved in defining SAccand also highlight that SAcc is way different from what political leaders and policymakers is pursuing about it. SAcc has madea more effective contribution in devising policies and procedures to improve public service delivery through using various techniques. Some of the techniques include increasing local constituent's information and voice, initiating trend of incentives for downward accountability, developing procedure for enhancing participatory monitoring, encouraging statecitizen dialogue and expedite the negotiation culture across parties (citizen and state).

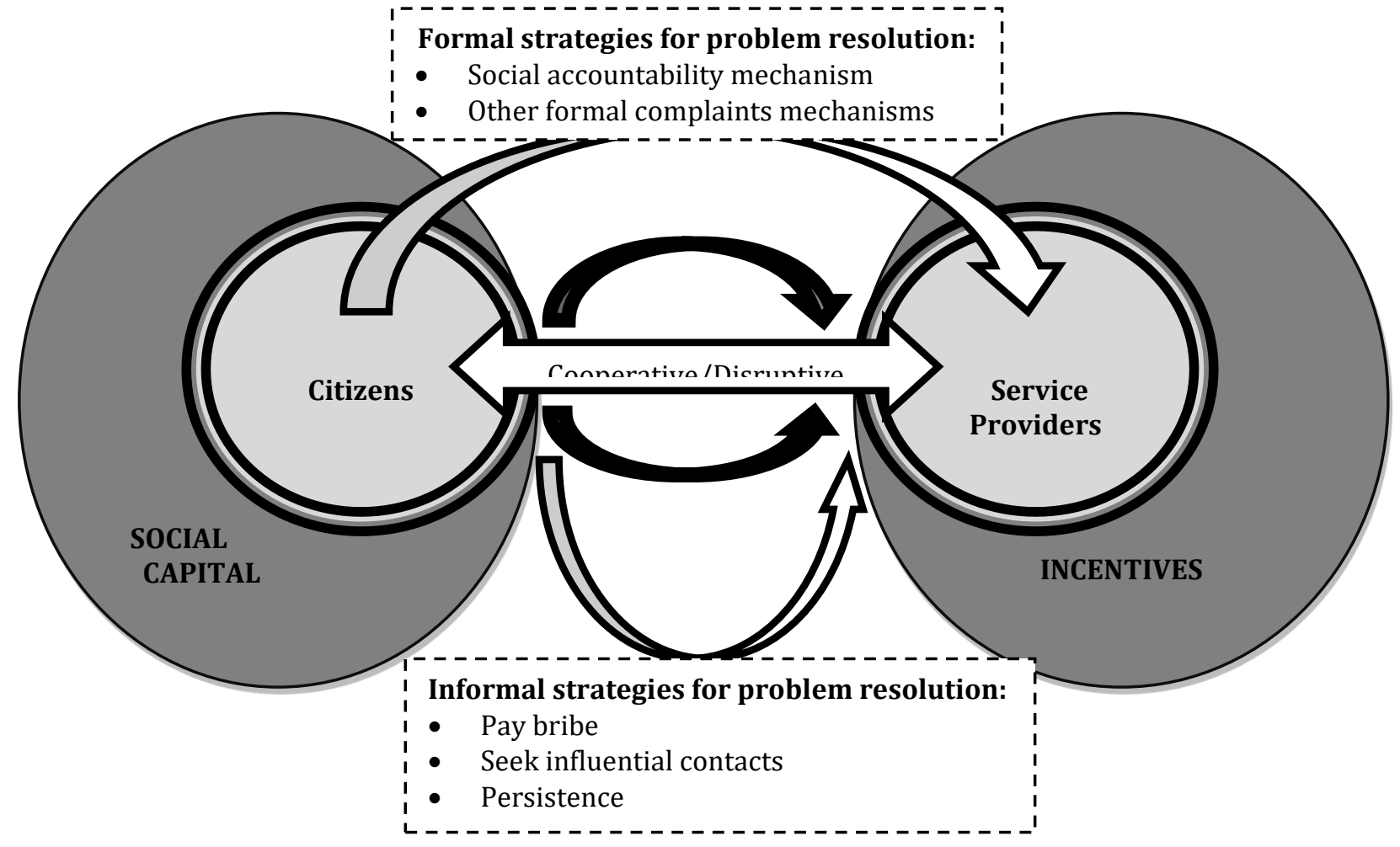

Figure 2: Determinants of Citizens - service Providers Relationship

Source: (Stahl, 2015: 11). 
Source of Empowerment: SAcc has one of the strongest sources to address the marginalized people of society. This system has been empowering the oppressed people to involve in the accountability mechanism which is the key component of empowerment accentuates the people's involvement in holding state actors accountable (World Bank, 2001). Considering the preceding, the SAcc initiative is a powerful tool that serves various key determinants of empowerment such as enhancing citizen's voices and influencing. More specifically SAcc is an imminent mechanism to involve underrepresented citizens of the society including youth, women, and poor people in holding the state accountable.

\section{CHALLENGES FOR IMPLEMENTING THE SACC}

Pakistan has been facing many constraints while implementing the SAcc within the country. However, the prevailing constraints are not very new in the case of Pakistan as South Asian countries were going through the same type of trauma while struggling to achieve good governance during civic engagement. These reported challenges are not only compiled from previously conducted studies, whereas the experiences of SDPI are also used as the primary source.

\section{The Resisting Attitude of State Officials towards Reforms}

Pakistan is a democratic state embedded with such governance system that operating under the patronized politics which always shows a great resistance towards accepting reforms within the state. The magisterial political system is the key reason for the existence of inefficient governance in the country. The official body did not want to open up a Pandora box which causes towards creating political unrest in the country. The research team has developed citizen report card for prospective assessments while the official ministry of education tries to camouflage their inherent deficiencies strictly asking government teachers to hold back their support with research team. The powerful people of the state do not want to expose themselves in front of the local constituents. They always resist to any of system that work on to audit their performance.

\section{Confusing Mechanism of Accountability Landscape}

It is important to be politically sagacious for the successful implementation of SAcc initiatives. The implementation of SAcc must be adaptable in existing complex political nexus of bureaucracy. The successful achievement of SAcc must be acquaintance with political actions that would include civil society organizations, interest groups, local constituents, and other stakeholders in the implementation process. Coventry and Hussein, (2010) emphasized that SAcc must be collegial with other governing bodies to get sustainable results. The beauty of SAcc practices generic framework is to be pro-poor people rather than elite, give opportunities to vulnerable to participate in holding state officials accountable.

\section{Powerful Vested Interest Leads towards Creating Disruption}

The government bodies and public officials have their vested interest in disruption in the implementation process of SAcc tools. The disruption can be taken from the rural areas where the civil society organizations are warned to leave the respective areas. In addition, the local constituents are asked to show their disruptive attitude with the NGO associated with SAcc projects. The officials generally report hostile behaviors of the communities specifically the religious representatives.

\section{Right to Information Act - Poor Implementation}

The freedom of speech and provision of public access to information are frequently reported in the literature as one of the significant prerequisites to hold the state accountable. (Coventry \& Hussein, 2010). There are many legislative laws supporting freedom of speech introduced in Pakistan; promulgation of right to information ordinance (2002) and recently inducted article 19A becomes part of the constitution. Article 19A claims that freedom of speech is the fundamental right of every citizen in Pakistan. However, the constitutional law is still not in compliance with the mechanism followed in public offices. The effective implementation of SAcc is not possible unless there is continuous availability of transparent and reliable information.

\section{Centralization}

Unfortunately, Pakistan possesses a feudal system where individuals, politicians, feudalism, are more powerful as compared to the institutions. These individuals of the country wield all the powers and authorities and exercise them without acknowledging the law and constitution.

\section{Poor Governance and Accountability Structure -}




\section{Stakeholders}

Presently, civil society organizations are playing a crucial role in initiating SAcc activities within the country to weed out governance crises in Pakistan. Civil society institutions are not following the defined governance and accountability systems. Many civil society firms resist sharing their transparency and accountability pointing to a big question mark on their credibility. These administrative bodies are losing the level of credibility in their voices rising for the implementation of SAcc.

\section{Environmental Constraints}

The supportive environment to implement SAcc doesn't exist in Pakistan. The supportive environment is based on various factors such as the presence of a legislative framework, formulated policies, acknowledging political milieu, and open-hearted, accessible, and receptive state. The civil society put on core efforts for the promotion of SAcc tools however, these efforts could not yield the expected outcomes. These weird results are sometimes due to the existence of prevailing loopholes in the legislation and constitution of the country. Despite showing dissatisfaction with the existing public service delivery mechanism, local constituents are unable to hold the state officials accountable.

\section{Political and Institutional Domain - Government, Civil Society Institutions Perspective}

The key purpose of the democratic system is to provide due rights and entitlements, safety, security, and social justice to the masses. Whereas the prevailing political parties are more of the elite. SAcc initiatives are more successfully promoted and practiced in an institutionalized milieu where the government is more willing to provide an open platform for the implementation of accountability projects at a large scale. The state is also obliged to contribute and strengthen civic engagement. The government is not always a reason for the weaker implementation of SAcc whereas, sometimes the citizen capabilities and capacities are also questionable.

\section{Performance Benchmarks - A Missing Element}

SAcc is an emerging field in the context of Pakistan but lacks to create a benchmark for an efficient public service delivery system. There are few tools such as Citizen Report Cards and Community Score Cards to serve as the first initiative to set the benchmarks.

\section{Social Mobilization and Media Exposure}

Community mobilization is crucial in making the local governance system accountable and answerable. It requires lots of effort to encourage and mobilize the community in rendering public officials accountable. The voices of local constituents are not considered without the endorsement of MPAs and MNAs. Similarly, it is rarely practiced in the domain of Pakistan that masses have taken collective decisions. The countries where masses are not aware to practice their due rights and they do not have freedom of speech until endorsed by the public officials are hardly stand out to speak about their constitutional rights. There are lots of efforts needed to be practiced in making the masses socially mobilize and educate them about their constitutional rights.

\section{POLICING THROUGH SOCIAL ACCOUNTABILITY}

The concept of SAcc is very novel in Pakistan which is not widely practiced in our culture. The concept consists of a broad range of actions to hold state actors accountable for their performances. Though article 19A of the constitution exists in the legislation book, unfortunately, the people of Pakistan are unaware of its legal verdict. This act gives each citizen of Pakistan the right to be informed but the promulgation of the legislation is a big question mark in the country. Additionally, another constraint of hinders ofSAcc is the lack of capability among the citizens to be empowered enough for fighting against the system for their rights (Joshi \& Houtzager, 2012). Although, the conception of SAcc is a new phenomenon in Pakistan the gender-based division of males and females in participating to hold the government accountable is another milestone achieved in this domain.

Societies, with varied socio-economic statuses, are well aware and recognize the value of the law-and-order machinery of the state. The law and order are a silent social contract between citizens and legislative bodies that confer authority to the state for law formulation which is ultimately implemented through institutions. Similarly, the institutions are based on various stakeholders including the judiciary, criminal agencies, health, education industry, and policing. All these institutions are jointly working to maintain and improve the quality of life of the citizen (Audit Commission, 2003). Triggering the level of trust can be upsurged through keeping proper checks and balances along with the development of the system of SAcc. This will ultimately 
help in developing a transparent mechanism to hold each other accountable for their remits (Home Office, 2003). Masses of the community are not aware of the processes and procedures used to hold these officials accountable. Unfortunately, the community even does not know the methods which can be undertaken to verify their accountability level and the officials intricate the system of accountability according to the convenience levels. They do not want to expose themselves in front of the local constituents who appoint them (Coleman, 2005). They believe that being citizens we know to whom (institutions) we are answerable for our performance, whereas the reality denounces this myth because indeed the reporting structure is unclear. Nobody knows who is answerable to whom, at what level, at what stage and who will hold the power to demand and realize this call for accountability (Day \& Klein, 1987). This uncertainty causes to eradicate the trust among various stakeholders. Community participation can only be initiated when citizens are well informed about the police authorities. The institutions setting up SAcc mechanism should have expertise in the relevant field while acquiring proper knowledge about the role and structure of the institution formations as an autonomous body (Myhill, 2003). In this modern era, debates on the accountability of police suggest that local accountability is the need of the hour (Jones, Newburn \& Smith, 1994). Many voices are being raised to create awareness about the rights and responsibilities of the citizens that is why there is a problem of crisis of legitimacy (Gaventa, 2002). People express their concerns about the role of police by saying that police lack responsiveness, use abusive language, and are grossly involved in corruption, favoritism (Narayan et al., 2000).

\section{FINDINGS}

Pakistan has been facing many constraints while implementing the SAcc within the country. However, the prevailing constraints have linkage with the situations as of South Asian countries. These countries were going through the same trauma when struggling to achieve good governance during civic engagement. The key findings are as under:

- Pakistan is a democratic state embedded with such a governance system that operates under patronized politics which always shows a great resistance towards accepting reforms within the state.
- Social accountability mechanisms are effective in challenging the status quo and making the government sensitive to listening to the community.

- Promoting public transparency helps to hold the government to be accountable.

- Empowerment of the community is key in making people aware of their rights and using them in a time of need.

- The government needs actual data to make informed decisions.

- Evidence-based approaches are a powerful tool to hold decision-makers accountable.

- Social accountability approaches are very costeffective since they promote adequate and effective way to use the existing resources from the government.

- Having an official and recognized platform can have an additional benefit, as it promotes confidence in raising issues within communities, not only about service provision but also collectively highlighting social challenges. The realization in society is a shift in social norms towards positive changes.

- SAcc is not very collegial with other governing developments to get sustainable results rather than to treat it in isolation.

- SAcc practices are empowering the pro-poor community than the elite.

- The government bodies and public officials have their vested interest that creating disruption in the implementation process of SAcc tools.

- Right to Information is the fundamental right of every citizen of the country, however; the constitutional law is still not in compliance with the mechanism followed in public offices.

- Politicians, (feudalism) are more powerful as compared to the institutions. These individuals of the country wield all the powers and authorities and exercise them without acknowledging the law and constitution.

- Civil society organizations are playing a crucial role in initiating SAcc activities within the country to weed out governance crises in Pakistan.

- Many civil society firms resist sharing their own transparency and accountability that creating a big question mark on the credibility of their work. 
- The civil society put hardcore efforts into the achievement and promotion of SAcc tools however, these efforts could not yield the expected outcomes. These weird results are sometimes due to the existence of prevailing loopholes in the legislation and constitution of the country.

- The prevailing politics are neglecting the rights of the pro-poor largely.

- The voices of local constituents do not consider unless endorsed by the MPAs and MNAs of the respective constituencies.

\section{CONCLUSION}

In the context of accountability, social accountability inventiveness can be critical. The process's result is the establishment of procedures for holding officials accountable for their actions. The process must incorporate public participation in quality assurance activities such as quality assessment and monitoring. This will promote actionable contributions toward discouraging corruption and rehabilitating governance. Not only will the reflection pique interest in social accountability avenues, but it will also broaden the scope of sectors and governance outcomes upon which the country will transform for the better in the health, security, and education sectors. Thus, social accountability can be an effective tool in the fight against corruption by empowering citizens to hold all departments accountable for their actions. This will result in a positive shift in all spheres of societal outlooks, ultimately resulting in good governance.

\section{REFERENCES}

Abbas, H. (2011). Reforming Pakistan 's Police and Law Enforcement Infrastructure. US Institute of Peace, Washington, $D C$.

Abbas, H. (2012). Stabilizing Pakistan through police Reform. Asia Society.

Ahmad, J. K., Devarajan, S., Khemani, S., \& Shah, S. (2005). Decentralization and service delivery. World Bank Policy Research Working Paper, (3603).

Ahmad, R. (2008). Governance, social accountability, and the civil society. JOAAG, 3(1), 10-21.

Andrews, M., and A. Shah. (2002). 'Voice Mechanisms and Local Government Fiscal Outcomes: How Does Civic Pressure and Participation Influence Public Accountability'. Processed. Washington, DC: The World Bank.
Annual Administration Report (2011). Police Headquarters Punjab accessed May 21, 2015, http://punjabpolice.gov.pk/system/files/Annual \%20 Admin\%20Report-2011.pdf.

Baez Camargo, C. (2015a). Communities against corruption. Assessment framework and methodological toolkit. Basel Institute on Governance Working Paper Series.

Behn, R. D. (2001). Rethinking democratic accountability. Brookings Institution Press.

Bhidal, F. Y. (2013). Social Accountability in Pakistan: Challenges, Gaps, Opportunities and the Way Forward. International Journal of Scientific and Research Publications, 69.

Bossert, T. (1998). Analyzing the Decentralization of Health Systems in Developing Countries: Decision Space, Innovation and Performance.' Social Science and Medicine 47 (10): 1513-27.

Bouwen, P. (2009). The European Commission. Lobbying in the European Union: Institutions, actors, and issues, 19-38.

Bovens, M., \& Curtin, D. (2010). The real world of EU accountability: what deficit? Oxford University Press.

Brookes, S. (2012). Police and Crime Commissioners are likely to be constrained by the need to swear allegiance to a political party. British Politics and Policy at LSE.

Camargo, C. B., \& Jacobs, E. (2013). Social Accountability and its Conceptual Challenges: An analytical framework. European Criminal Law Associations Forum working paper, 16.

Cheema, U. (2011). "KP Differs with Sindh, Balochistan on Police Order, LB Laws," The News (Pakistan), October 25, 2011, accessed June 20, 2015, http://www.thenews.com.pk/Todays-News-139825-KP-differs-with-Sindh-Balochistan-onpolice-order-LB-laws.

Das, D., and Otwin, M. (2012). Challenges of policing democracies: A world perspective. Routledge.

Day, P., \& Klein, R. (1987). Accountabilities: five public services (Vol. 357). Taylor \& Francis

Dubnick, M. J. (2007). Sarbanes-Oxley and the search for accountable corporate governance. GovNeteJournal, 1(2), 140-72.

Elock, H. (1996). "Local Government”. In: Farnham, D. and Horton, S (eds.), Managing the New Public Services. pp. 177-199. London: MacMillan Press. 
Evans, Peter, W.F. Lam, E. Heller, J. Fox, and M. Burawoz. (1996). 'Government Action, Social Capital and Development: Creating Synergy Across the PublicPrivateDavie'. World Development Special Section 24 (6): 1033-1132.

Fetterman, D. M., Kaftarian, S. J., \&Wandersman, A. (1996). Empowerment evaluation: Knowledge and tools for self-assessment and accountability. Sage.

Foley, Michael W., and Bob Edwards. (1996). 'The Paradox of Civil Society'. Journal of Democracy 7 (3): 38-52.

Fox, Jonathan. (1996). 'How Does Civil Society Thicken? The Political Construction of Social Capital in Rural Mexico'. World Development 24 (6): 1089-1103.

Fukuyama, Francis. (2001). 'Social Capital, Civil Society and Development'. Third World Quarterly 22 (1): 7-20. doi:10.1080/713701144.

Gaventa, John, and Gregory Barrett. (2010). 'So, What Difference Does It Make? Mapping the Outcomes of Citizen Engagement'. IDS Working Paper 347.

Goetz, A. M., \&Gaventa, J. (2001). Bringing citizen voice and client focus into service delivery. Brighton: Institute of Development Studie, IDS working paper. $p$ (No. 138).

Goetz, A. M., \& Jenkins, R. (2001). Hybrid forms of accountability: citizen engagement in institutions of public-sector oversight in India. Public Management Review, 3(3), 363-383.

Hart, V. (1978). Distrust and democracy: Political distrust in Britain and America. Cambridge University Press.

Heiden, P. (2011). Pakistan. ABDO. pp. 33-44. Retrieved 11 March 2015. http://www.gnosticbooks.org/book/9781617831 171/pakistan

Imtiaz, H. (2011). TheIslam that hard-liners hate. Retrieved 11 April 2015 from http://atwar.blogs.nytimes.com/2011/01/06/the -islam-that-hard-liners-hate/?_r=0

Javaid, U., \& Ramazan, M. (2013). Police Order 2002: A Critique, Journal of Political Studies, 20(2), 141160

Johnston, M. (2014). Corruption Contention and Reform. The Power of Deep Democratization. NY: Cambridge University Press.

Jones, T. M., \& Wicks, A. C. (1999). Convergent stakeholder theory. Academy of management review, 24(2), 206-221.
Jones, T., Newburn, T., \& Smith, D. J. (1996). Policing and the Idea of Democracy. British Journal of Criminology, 36(2), 182-198.

Joshi, A., \& Houtzager, P. P. (2012). Widgets or watchdogs? Conceptual explorations in social accountability. Public Management Review, 14(2), 145-162.

Khan, S. R., Kazmi, S., \& Latif, Z. (1999). The state of basic education in Pakistan: A qualitative, comparative institutional analysis. Sustainable Development Policy Institute.

Kilby, P. (2006). Accountability for empowerment: Dilemmas facing non-governmental organizations. World Development, 34(6), 951-963.

Lackey, D. P. (2006). The Good Soldier versus the Good Cop: Counterterrorism as Police Work. 66-82.

Loveday, B. (2005). The challenge of police reform in England and Wales.Public Money and Management, 25(5), 275-281.

Loveday, B., \& Reid, A. (2003). Going local. Who should run Britain's police?

Malena, C., \& Forster, R. (2004). Social Accountability An introduction to the concept and emerging practice.

Malena, C., \& Forster, R. (2004). Social Accountability An introduction to the concept and emerging practice.

McCandless, H. E. (2002). A citizen's guide to public accountability: Changing the relationship between citizens and authorities. Trafford Publishing.

McGee, Rosemary, and John Gaventa. (2010). 'Review of Impact and Effectiveness of Transparency and Accountability Initiatives'. Institute of Development Studies. http://www.ids.ac.uk/index.cfm?objectid=7E 5D1074-969C-58FC7B586DE3994C885C.

Meijer, A. J. (2004). Stakeholder accountability in an information age. In EGPA 2004 Annual Conference, Ljubljana/Slovenia (pp. 1-4).

Mohmand, S. K., \& Cheema, A. (2007). Accountability failures and the decentralization of service delivery in Pakistan. IDS Bulletin, 38(1), 45-59.

Moore, M. H. (1995). Creating public value: Strategic management in government. Harvard university press.

Moore, M. H. (2000). Managing for value: Organizational strategy in for-profit, nonprofit, and governmental organizations. Nonprofit and Voluntary Sector Quarterly, 29(suppl 1), 183-208. 
Mungiu-Pippidi, Alina. (2014). 'Quantiative Report on Causes of Perfromance and Stagnation in the Global Fight against Corruption.' ANTICORRP research consortium.

Myhill, A., Dalgleish, D., Docking, M., \& Yarrow, S. (2003). The role of police authorities in public engagement. United Kingdom. Home Office.

Niaz, I. (2006). An Inquiry into the Culture of Power of the Subcontinent. Alhamra.

O’Meally, Simon C. (2013). 'Mapping Context for Social Accountability'. The World Bank. http://siteresources.worldbank.org/EXTSOCIALD EVELOPMENT/Resources/244362$1193949504055 /$ Context and SAcc RESOURCE_P APER.pdf.

Park, V., \&Datnow, A. (2009). Co-constructing distributed leadership: District and school connections in datadriven decision-making. School leadership and Management, 29(5), 477-494.

Pollitt, C., \& Summa, H. (1997). Reflexive watchdogs? What supreme audit institutions account for themselves? Public Administration, 75(2), 313-336.

Putnam, Robert D. (1995). 'Bowling Alone: America's Declining Social Capital'. Journal of Democracy 6 (1): 65-78. doi:10.1353/jod.1995.0002.

Raine, J. W., \& Dunstan, E. (2007). Continuing the Discussion on Community Policing, Issue 2Enhancing Accountability in Local Policing. Policing, 1(3), 327-341.

Schedler, A., Diamond, L., \& Plattner, M. F. (1999). Restraining the state: conflicts and agents of accountability. The self-restraining state: Power and accountability in new democracies, 333-50.

Schillemans, T., \&Bovens, M. (2004). Horizontaleverantwoordingbijzelfstandigebestuur sorganen. Governance van

uitvoeringsorganisaties:

Nieuwevraagstukkenvoorsturing in het publiekedomein, Apeldoorn: Kadaster, 27-37.

Schouten, Claire. (2011). 'Social Accountability in Situations of Conflict and Fragility'. U4Brief No.19.

Sinclair, A. (1995). The chameleon of accountability: Forms and discourses. Accounting, organizations and Society, 20(2), 219-237.

Stahl, F. (2015). Social accountability: A practitioner's handbook. Switzerland: Basel Institute of Governance.

Strøm, K., Müller, W. C., \& Bergman, T. (2006). Delegation and accountability in parliamentary democracies (Vol. 42). Oxford University Press.

Suddle, M. S. (2003). Reforming Pakistan Police: An Overview. United Nations Asia and.

United Nations Development Programme (2014). Human Development Report Summary, in Lloyd-Jones, T., \&Rakodi, C. (Eds.). Urban livelihoods: A peoplecentred approach to reducing poverty. Routledge. 21-25

Watson, D., \& Khan, A. Q. (2005). Capacity Building for decentralized education service delivery in Pakistan (Vol. 57). Discussion Paper.

World Bank (2001). Filipino Report Card on Pro-Poor Services: Summary. Environment and Social Development Unit, East Asia and Pacific Region. Washington: World Bank.

Yaseen, F. (2013). Social Accountability in Pakistan: Challenges, Gaps, Opportunities and the Way Forward. Working Paper no. 133, Islamabad: Sustainable Development Policy Institute (SDPI).

Publisher's note: EScience Press remains neutral with regard to jurisdictional claims in published maps and institutional affiliations.

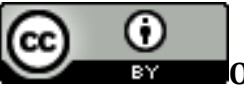

Open Access This article is licensed under a Creative Commons Attribution 4.0 International License, which permits use, sharing, adaptation, distribution and reproduction in any medium or format, as long as you give appropriate credit to the original author(s) and the source, provide a link to the Creative Commons license and indicate if changes were made. The images or other thirdparty material in this article are included in the article's Creative Commons license, unless indicated otherwise in a credit line to the material. If material is not included in the article's Creative Commons license and your intended use is not permitted by statutory regulation or exceeds the permitted use, you will need to obtain permission directly from the copyright holder. To view a copy of this license, visit http://creativecommons.org/licenses/by/4.0/.

(C) The Author(s) 2021. 